\title{
Correlación clínico-citohistológica de los quistes congénitos cervicales
}

\author{
Clinical-cytohistological correlation of cervicofacial congenital cysts
}

Los autores plantean un estudio de correlación entre los diagnósticos clínicos y citológicos de las masas quísticas congénitas cervicofaciales. Utilizan repetidamente las siglas BAAF procedentes de Biopsia por Aspiración con Aguja Fina. Esto resulta confuso ya que la prueba que se somete a análisis en el artículo obtiene material citológico y no histopatológico. El término PAAF como siglas de Punción Aspiración con Aguja Fina se encuentra ampliamente aceptado y difundido en la literatura de habla hispana. La biopsia quirúrgica con su estudio histopatológico es la prueba de confirmación (Gold standard).

En la introducción se hace una descripción muy somera de los quistes cervicales. Los autores restringen su estudio a tres tipos de quiste cervical congénito como son los del conducto tirogloso, los quistes branquiales y los dermoides, aún cuando hay otros que ellos mismos citan, como son los linfangiomas cavernosos (higromas quísticos), los quistes paratiroideos, broncogénicos, tímicos, laringoceles, teratomas, etc. y algunos más que merecen una atención clínica. ${ }^{(1-3)}$

En la descripción de los quistes que van a tratar posteriormente, se comenta el aspecto macroscópico del contenido de uno de ellos, el quiste dermoide. Dicen que la cavidad está llena «de material seroso». El material seroso (parecido al suero) no es propio de este tipo de quiste. En el quiste dermoide se obtiene un material pastoso constituido por queratina y grasa prodente de la secreción de los anejos dérmicos que se encuentran en la pared del mismo. En la citada descripción no se hace referencia a la estructura histopatológica de las lesiones. Es un dato que no sólo tiene interés académico sino también práctico y ayuda a explicar los resultados de las citologías. Los quistes tiroglosos altos tienen un revestimiento escamoso, mientras los bajos tienen un revestimiento de epitelio cúbico. En la pared puede haber folículos tiroideos, por lo que en la aspiración se puede reconocer material coloide y células foliculares. Sólo en este último caso se puede hacer el diagnóstico citológico de certeza.

El quiste branquial cuyo contenido suele ser macroscópicamente de aspecto mucoide, también puede estar revestido por epitelio cúbico, cilíndrico ciliado o escamoso por lo que su diagnóstico diferencial con el quiste tirogloso puede ser muy difícil desde el punto de vista estrictamente citológico. Es bien conocido que el quiste branquial tiene un componente linfoide bien organizado en su pared. En la punción la presencia de este componente junto a elementos epiteliales benignos nos induce a un diagnóstico de quiste branquial, pero siempre teniendo en cuenta su localización ya que algunos quiste linfoepiteliales de glándula salival muestran un aspecto muy similar.

La citología del quiste dermoide es imposible de diferenciar de la del quiste infundibular ya que ambas muestran gran cantidad de células escamosas intermedias y superficiales con restos de queratina.

Otros quistes como el paratiroideo necesitan otra técnicas, como la demostración de hormona paratiroidea (PTH) en el líquido para su confirmación. ${ }^{(2,4)}$

En la discusión se plantean de forma muy lógica las posibilidades ante una tumoración cervical y se incluyen además de la naturaleza
The authors establish a correlation study between the clinical and cytological diagnoses of cervicofacial congenital cystic masses. They repeatedly use the abbreviation FNAB for Fine Needle Aspiration Biopsy. This is confusing since the test subjected to analysis in the article obtains cytological and not histopathological material. The term FNAP (PAAF in Spanish) as abbreviation of Fine Needle Aspiration Puncture is widely accepted and published in the Spanish language literature. Surgical biopsy with its histopathological study is the gold standard. A very short description is made of the cervical cysts in the introduction. The authors restrict their study to three types of congenital cervical cysts, these being thyroglossal duct, branchial and dermoid cysts, even though there are others that they mentioned such as cavernous lymphangiomas (cystic hygromas), parathyroid, bronchogenic, thymic, laryngocele, teratoma cysts, etc. and some more that deserve clinical attention. ${ }^{(1-3)}$

In the description of the cysts that they deal with later on, the gross aspect of the content of one of them, the dermoid cyst, is commented on. They state that the cavity is full "of serous material». The serous material (similar to serum) is not characteristic of this type of cyst. In the dermoid cyst, a pasty material made up of keratin and fat from the secretion of the dermal appendages found in its wall is obtained.

In the mentioned description, no reference is made to the histopathological structure of the lesions. It is information that not only has academic but also practical interest and helps to explain the cytology results. The thyroglossal cysts in the upper neck have a squamous lining, while in the lower neck, they have a cubic epithelial lining. There may be thyroid folicules in the wall so that colloid material and folicular cells may be recognized in the aspiration. The certainty cytological diagnosis can only be made in the latter case.

The branchial cyst whose content generally has a gross mucoid appearance may also be lined by cubic, ciliated cylindrical or squamous epithelium so that its differential diagnosis with the thyroglossal cyst may be very difficult from the strictly cytological point of view. It is well known that the branchial cyst has a well organized lymphoid component in its wall. In the puncture, the presence of this component, together with benign epithelial elements, lead us to a branchial cyst diagnosis, but always taking its location into account since some lymphoepithelial cysts of the salivary gland show a very similar appearance.

The dermoid cyst cytology is impossible to differentiate from that of the infundibular cyst since both show a large amount of intermediate and superficial squamous cells with keratin remains. 
congénita, la infecciosa (inflamatoria en general) y la neoplásica. Los datos clínicos de edad, localización, tiempo de evolución, antecedentes, etc., proporcionan una aproximación muy importante al diagnóstico que, como apuntan los autores, se ve reforzada por la comprobación por PAAF.

En su casuística el diagnóstico clínico diferencial se plantea frecuentemente con la linfadenopatía reactiva. En nuestra experiencia, sin embargo, la sospecha clínica con la que llegan estos pacientes es de malignidad: metástasis o linfoma, ya que las lesiones quísticas suelen adquirir un tamaño que hace sospechar malignidad. La rentabilidad de la PAAF en este tipo de diagnóstico diferencial es obviamente mucho mayor que la del diagnóstico clínico y el objetivo principal de la misma(5,6).

De la discusión que hace los autores se podría deducir la siguiente pregunta: ¿Puede la PAAF desde un punto de vista de eficacia, economía, rapidez, etc., evitar las técnicas de imagen?

La respuesta no está aclarada y probablemente se ajuste a las necesidades de cada centro. Cuando la demora en las pruebas de imagen es muy alta, es evidente que los clínicos acudirán a la PAAF como método de confirmación de su impresión diagnóstica. Sin embargo, la situación ideal pasaría por realizar las técnicas de imagen antes de la PAAF con lo que la seguridad del diagnóstico se situaría muy cercana al $100 \%$. La PAAF, por muy inocua que sea, altera la imagen radiológica o ecográfica de la lesión. Conocer la localización exacta de la lesión y de la estructura de la que depende ayuda enormemente a su diagnóstico correcto, especialmente en las lesiones menos frecuentes como pueden ser los quistes tímicos, linfangiomas o quistes paratiroideos en los que, ante su sospecha, se puede solicitar la detección de PTH en el líquido, lo que daría la clave del diagnóstico. Por otra parte, se evitan situaciones que pueden resultar peligrosas como la punción de paragangliomas.

\section{J.A. López García-Asenjo \\ Servicio de Anatomía Patológica Hospital Clínico San Carlos. Madrid, España}

\section{Bibliografía}

1. Tsai MH, Chu SM, Huang SF. Congenital esophageal duplication cyst: report of two cases. Acta Paediatr Taiwan 2003;44:307-9.

2. Armstrong J, Leteurtre E, Proye C. Intraparathyroid cyst: a tumour of branchial origin and a possible pitfall for targeted parathyroid surgery. ANZ / Surg 2003;73:1048-51.

3. El Hag IA, Chiedozi IC, al Reyees FA, Kollur SM. Fine needle aspiration cytology of head and neck masses. Seven years'experience in a secondary care hospital. Acta Cytol 2003;47:387-92.

4. Espinoza L, Molina MA, Gonzalez I, Gracia R. Parathyroid cyst in the differential diagnosis of neck masses. A Case Report. An Pediatr (Barc) 2003;58:188-90.

5. Ustun M, Risberg B, Davidson B, Berner A. Cystic change in metastatic lymph nodes: a common diagnostic pitfall in fine-needle cytology. Diagn Cytoptahol 2002;27:387-92.

6. Costas A, Castro P, Martín-Granizo R, Monje F, Marrón C, Amigo A. Fine needle aspiration biopsy (FNAB) for lesions of the salivary glands. Br J Oral Maxillofac Surg 2000;38:539-42.
Other cysts such as the parathyroid one need other techniques like the demonstration of parathyroid hormone in the liquid (PTH) for its confirmation. $(2,4)$

The possibilities when faced with a cervical tumor are very logically established in the discussion and in addition to the congenital nature, the infectious (inflammatory in general) and neoplastic nature are also included. Clinical data of age, location, evolution time, background, etc provide a very important approximation to the diagnosis which, as the authors state, is reinforced through FNAP verification.

In their casuistry, the differential clinical diagnosis is frequently suggested with reactive lymphadenopathy. Howev$e r$, in our experience, these patients arrive with the clinical suspicion of malignancy: metastasis or lymphoma since the cystic lesions generally acquire a size that leads to the suspicion of malignancy. The profitability of the FNAP in this type of differential diagnosis is obviously much greater than that of the clinical diagnosis and its main objective. $(5,6)$

From the discussion of the authors, the following question can be deduced: From the point of view of efficacy, economy, fastness, etc, can the FNAP avoid imaging techniques?

The result is not clarified and probably adjusts to the needs of each center. When the delay in the imaging tests is very high, it is evident that the clinicians will use the FNAP as confirmation method of their diagnostic impression. However, the ideal situation would be to perform the imaging techniques before the FNAP so that the diagnostic certainty would be close to $100 \%$. The FNAP, however harmless it is, alters the radiological or ultrasonographic image of the lesion. Knowing the exact site of the lesion and of the structure it depends on enormously helps its correct diagnosis, especially in the least frequent lesions such as thymic cysts, lymphangiomas or parathyroid cysts in which, due to suspicion, detection of PTH in liquid may be requested, which would provide the key to the diagnosis. On the other hand, situations that may be dangerous, such as paraganglioma puncture, are avoided. 